\title{
Pembelajaran Kooperatif Tipe CIRC
}

\author{
Nursakiah \\ Pendidikan Matematika FKIP Universitas Muhammadiyah Makassar \\ e-mail : sackyah@gmail.com
}

\begin{abstract}
Abstrak
Penelitian ini adalah penelitian tindakan kelas yang bertujuan untuk meningkatkan hasil belajar matematika siswa di Kelas VII SMP. Data hasil penelitian diambil dari data kuantitatif berupa tes hasil belajar pada siklus I dan siklus II, dan data kualitatif berupa hasil observasi siswa dan guru. Hasil penelitian ini menunjukkan bahwa: 1) hasil belajar matematika siswa siklus I berada pada kategori sedang dengan skor rata-rata 54,47 dari skor ideal 100 dengan standar deviasi 16,24 dan ketuntasan belajar secara klasikal sebesar 46,7\%. 2) hasil belajar matematika siswa siklus II berada pada kategori tinggi dengan skor rata-rata 69,34 dari skor ideal 100 dengan standar deviasi 11,01 dan ketuntasan belajar secara klasikal sebesar 87,5\%. 3) model pembelajaran kooperatif tipe CIRC dapat meningkatkan hasil belajar matematika siswa kelas VII4 SMP Negeri 26 Makassar. Hasil observasi menunjukkan adanya perubahan sikap siswa antara lain siswa menjadi lebih aktif dalam proses belajar dan motivasi siswa untuk belajar meningkat, keberanian siswa bertanya materi pelajaran yang belum dimengerti dan siswa yang percaya diri mengerjakan soal di papan tulis mengalami peningkatan. Hal ini menunjukkan bahwa semangat, kreativitas, keberanian dan rasa percaya diri siswa mengalami peningkatan setelah diterapkan pembelajaran model pembelajaran kooperatif tipe CIRC.
\end{abstract}

Kata Kunci: pembelajaran kooperatif, CIRC, penelitian tindakan kelas

\section{PENDAHULUAN}

Keberhasilan proses pembelajaran matematika dapat diukur dari keberhasilan siswa yang mengikuti kegiatan pembelajaran tersebut. Semakin tinggi pemahaman dan penguasaan serta prestasi belajar maka semakin tinggi pula tingkat keberhasilan pembelajaran. Namun pada kenyataannya dapat dilihat bahwa prestasi belajar matematika yang dicapai siswa masih rendah.

Sedangkan Abdurrahman (1999) berpendapat bahwa hasil belajar adalah kemampuan yang diperoleh anak setelah melalui kegiatan belajar. Belajar itu sendiri merupakan suatu proses dari seseorang yang berusaha untuk memperoleh suatu bentuk perubahan perilaku yang relatif menetap. Dalam kegiatan belajar yang terprogram dan terkontrol yang disebut sebagai kegiatan pembelajaran atau kegiatan instruksional, tujuan belajar ditetapkan lebih dahulu oleh guru. Anak yang berhasil dalam belajar adalah yang berhasil mencapai tujuan-tujuan pembelajaran atau tujuan-tujuan instruksional. Jadi, agar hasil belajar dapat diperoleh dengan diperlukan suatu model pembelajaran yang tepat, menarik dan harus efektif sehingga siswa dapat aktif dalam kegiatan pembelajaran dan dapat menghasilkan apa yang harus dikuasai siswa setelah proses pembelajaran berlangsung salah satunya yaitu model pembelajaran kooperatif. Dalam model pembelajaran kooperatif siswa belajar bersama dalam kelompok-kelompok kecil yang 
bekerja untuk menyelesaikan suatu masalah, menyelesaikan suatu tugas atau mengerjakan sesuatu untuk mencapai tujuan bersama. Salah satu model pembelajaran kooperatif dalam pembelajaran matematika yang memenuhi ciri pembelajaran efektif diantaranya model pembelajaran kooperatif tipe CIRC.

Model pembelajaran kooperatif tipe CIRC dipilih sebagai alternatif yang dapat digunakan untuk mengatasi masalah hasil pembelajaran matematika siswa SMP Negeri 26 Makassar dengan pertimbangan bahwa pada umumnya siswa di sekolah ini memiliki karakter jika diberikan penghargaan atas keberhasilannya dalam belajar. Di samping itu siswa juga senang berkompetisi dalam meraih hasil belajar yang tinggi. Namun demikian kemampuan matematika siswa cukup heterogen dalam arti bahwa ada perbedaan yang cukup jauh antar siswa dalam pemahaman matematika.

Pembelajaran kooperatif mencakup suatu kelompok kecil siswa yang bekerja sebagai suatu tim untuk menyelesaikan sebuah masalah, menyelesaikan suatu tugas, atau mengerjakan sesuatu untuk mencapai tujuan bersama lainnya. Pembelajaran kooperatif menekankan pada kehadiran teman sebaya yang berinteraksi antara sesamanya sebagai sebuah tim dalam menyelesaikan atau membahas suatu masalah atau tugas dalam Suherman (2003).

Pembelajaran kooperatif adalah suatu sistem yang didalamnya terdapat elemenelemen yang saling terkait. Empat elemen dalam pembelajaran kooperatif yaitu adanya: “(1) Saling ketergantungan positif, (2) Interaksi tatap muka, (3) Akuntabilitas individual, dan (4) Keterampilan untuk menjalin hubungan antar pribadi atau keterampilan sosial yang secara sengaja diajarkan" Abdurrahman \& Bintoro yang dikutip oleh Nurhadi, dkk., (2003).

Dalam penerapannya dalam pembelajaran di kelas, pembelajaran kooperatif dapat dilakukan dalam beberapa metode. Slavin (2008) mengemukakan beberapa metode pembelajaran kooperatif, yaitu: Metode STAD (Student Teams Achiement Divisions), Metode Jigsaw, Metode TGT (Teams Games Tournament), Metode TAI (Team Accelerated Individualization) dan Metode CIRC.

Hasil penelitian yang dilakukan oleh Johnson dan Johnson yang dikutip oleh Nurhadi, dkk (2004) menunjukkan ada tiga puluh tiga keunggulan pembelajaran kooperatif, yaitu:

1. Memudahkan siswa melakukan penyesuaian sosial;

2. Mengembangkan kegembiraan belajar yang sejati;

3. Memungkinkan para siswa saling belajar mengenai sikap, keterampilan, informasi, perilaku sosial, dan pandangan;

4. Memungkinkan terbentuk dan berkembangnya nilai-nilai sosial dan komitmen;

5. Meningkatkan keterampilan metakognitif;

6. Menghilangkan sifat mementingkan diri sendiri atau egois dan egosentris;

7. Meningkatkan kepekaan dan kesetiakawanan sosial;

8. Menghilangkan siswa dari penderitaan akibat kesendirian atau keterasingan;

9. Dapat menjadi acuan bagi perkembangan kepribadian yang sehat dan terintegrasi;

10. Membangun persahabatan yang dapat berlanjut hingga masa dewasa;

11. Mencegah timbulnya gangguan kejiwaan;

12. Mencegah terjadinya kenakalan dimasa remaja;

13. Menimbulkan perilaku rasional dimasa remaja;

14. Berbagi keterampilan sosial yang diperlukan untuk memelihara hubungan saling membutuhkan dapat diajarkan dan dipraktekkan;

15. Meningkatkan rasa saling percaya antara sesama manusia;

16. Meningkatkan kemampuan memandang masalah dan situasi dari berbagai perspektif;

17. Meningkatkan perasaan penuh makna mengenai arah dan tujuan hidup; 
18. Meningkatkan keyakinan terhadap ide tau gagasan sendiri;

19. Meningkatkan kesediaan mengguanakan ide orang lain yang dirasakan lebih baik;

20. Meningkatkan motivasi belajar intrinsik;

21. Meningkatkan kegemaran berteman tanpa memandang perbedaan kemampuan, jenis kelamin, normal atau cacat, etnis, kelas sosial, agama, dan orientasi tugas;

22. Mengembangkan kesadaran bertanggung jawab dan saling menjaga perasaan;

23. Meningkatkan sikap positif terhadap belajar dan pengalaman belajar;

24. Meningkatkan keterampilan hidup bergotong royong;

25. Meningkatkan kesehatan psikologis;

26. Meningkatkan sikap tenggang rasa;

27. Meningkatkan kemampuan berpikir divergen atau berpikir kreatif;

28. Memungkinkan siswa mampu mengubah pandangan klise dan stereotip menjadi pandangan yang dinamis dan realistis;

29. Meningkatkan rasa harga diri (self-esteem) dan penerimaan diri (self-acceptance);

30. Memberikan harapan yang lebih besar bagi terbentuknya manusia dewasa yang mampu menjalin hubungan positif dengan sesamanya, baik di tempat kerja maupun di masyarakat;

31. Meningkatkan hubungan positif antara siswa dengan guru dan personel sekolah;

32. Meningkatkan pandangan siswa terhadap guru yang bukan hanya sebagai penunjang keberhasilan akademik tetapi juga perkembangan kepribadian yang sehat dan terintegrasi;

33. Meningkatkan pandangan siswa terhadap guru yang bukan hanya pengajar tetapi juga pendidik.

Pada model pembelajaran koopertif terdapat langkah-langkah pembelajaran yang terdiri atas enam fase yaitu 1) menyampaikan tujuan dan memotivasi siswa, 2) menyajikan informasi, 3) mengorganisasikan siswa ke dalam kelompok-kelompok belajar, 4) membimbing kelompok bekerja dan belajar, 5) evaluasi, dan 6) memberikan penghargaan Nurdin (2009).

CIRC (Cooperative Integrated Reading and Composition), termasuk salah satu tipe model pembelajaran kooperatif. Pada awalnya, model CIRC diterapkan dalam pembelajaran bahasa. Dalam kelompok kecil, para siswa diberi suatu teks/bacaan (cerita atau novel), kemudian siswa latihan membaca atau saling membaca, memahami ide pokok, saling merevisi, dan menulis ikhtisar cerita atau memberikan tanggapan terhadap isi cerita, atau untuk mempersiapkan tugas tertentu dari guru dikutip dari Nur dalam Mazjun (2010) yaitu sebuah program komprehensif atau luas dan lengkap untuk pengajaran membaca dan menulis untuk kelas-kelas tinggi sekolah dasar. Namun, CIRC telah berkembang bukan hanya dipakai pada pelajaran bahasa tetapi juga pelajaran eksak seperti pelajaran matematika.

Dalam model pembelajaran CIRC, siswa ditempatkan dalam kelompok-kelompok kecil yang heterogen, yang terdiri atas 4 atau 5 siswa. Dalam kelompok ini tidak dibedakan atas jenis kelamin, suku/bangsa,atau tingkat kecerdasan siswa. Jadi, dalam kelompok ini sebaiknya ada siswa yang pandai, sedang atau lemah, dan masing-masing siswa sebaiknya merasa cocok satu sama lain. Dengan pembelajaran kelompok, diharapkan para siswa dapat meningkatkan pikiran kritisnya, kreatif, dan menumbuhkan rasa sosial yang tinggi. Sebelum dibentuk kelompok, siswa diajarkan bagaimana bekerja sama dalam suatu kelompok. Siswa diajari menjadi pendengar yang baik, dapat memberikan penjelasan kepada teman sekelompok, berdiskusi, mendorong teman lain untuk bekerja sama, menghargai pendapat teman lain, dan sebagaimya. Salah satu ciri pembelajaran kooperatif adalah kemampuan siswa untuk bekerja sama dalam kelompok kecil yang heterogen. Masing-masing anggota dalam kelompok memiliki tugas yang 
setara. Karena pada pembelajaran kooperatif keberhasilan kelompok sangat diperhatikan, maka siswa yang pandai ikut bertanggung jawab membantu temannya yang lemah dalam kelompoknya. Dengan demikian, siswa yang pandai dapat mengembangkan kemampuan dan keterampilannya, sedangkan siswa yang lemah akan terbantu dalam memahami permasalahan yang diselesaikan dalam kelompok tersebut.

Model pembelajaran kooperatif tipe CIRC menurut Suyitno dalam Inayah (2010) memiliki delapan komponen. Kedelapan komponen tersebut antara lain: (1) Teams, (2) Placement test, (3) Student creative, (4) Team study, (5) Team scorer and team recognition, (6) Teaching group, (7) Facts test, (8) Whole- class units.

Suyitno (Inayah, 2007) mengungkapkan kegiatan pokok dalam dalam pembelajaran koopratif tipe CIRC, yaitu sebagai berikut: (1) salah satu anggota kelompok membaca atau beberapa anggota membaca soal, (2) membuat prediksi atau menafsirkan atas isi soal pemecahan masalah, termasuk menuliskan apa yang diketahui, apa yang ditanyakan, dan memisalkan yang ditanyakan dengan suatu variabel tertentu, (3) saling membuat ikhtisar atau rencana penyelesaian soal pemecahan masalah, (4) menuliskan penyelesaian soal pemecahan masalah secara urut (menuliskan urutan komposisi penyelesaiannya), (5) saling merevisi dan mengedit pekerjaan/penyelesaian (jika ada yang perlu direvisi).

Hal ini dilengkapi dengan pendapat Suyitno dalam Rosyadi (2010) menyebutkan beberapa kelebihan model pembelajaran kooperatif tipe CIRC sebagai berikut: (1) CIRC amat tepat untuk meningkatkan keterampilan siswa dalam menyelesaikan soal pemecahan masalah, (2) dominasi guru dalam pembelajaran berkurang, (3) siswa termotivasi pada hasil secara teliti, karena bekerja dalam kelompok, (4) para siswa dapat memahami makna soal dan saling mengecek pekerjaannya, (5) Membantu siswa yang lemah, (6) Meningkatkan hasil belajar khususnya dalam menyelesaikan soal yang berbentuk pemecahan masalah.

Dalam hal ini, keterlibatan setiap siswa untuk belajar secara aktif merupakan salah satu indikator keefektifan belajar. Dengan demikian, siswa tidak hanya menerima saja materi pengajaran yang diberikan guru, melainkan siswa juga berusaha menggali dan mengembangkan sendiri dalam kelompoknya.

Berdasarkan latar belakang yang telah dikemukakan penulis termotivasi untuk melakukan penelitian tindakan kelas dengan menerapkan model pembelajaran kooperatif tipe CIRC khususnya pada pokok bahasan Segiempat karena materi tersebut diajarkan dikelas VII4 SMP Negeri 26 Makassar. Penelitian ini berjudul "Peningkatan Hasil Belajar Matematika Melalui Penerapan Model Pembelajaran Kooperatif Tipe CIRC Pada Siswa Kelas VII4 SMP Negeri 26 Makassar".

\section{METODE PENELITIAN}

Penelitian ini merupakan penelitian tindakan kelas yang dilakasanakan dengan dua siklus yang pelaksanaannya meliputi empat tahap, yaitu perencanaan, tindakan, observasi/evaluasi dan refleksi. Subjek penelitian adalah siswa Kelas VII4 SMP Negeri 26 Makassar pada semester genap tahun ajaran 2010/2011.

Data dan teknik pengumpulannya yaitu (1) data mengenai aktivitas siswa dalam proses belajar mengajar dipeoleh dengan melakukan pengamatan menggunakan lembar observasi aktivitas siswa, (2) data mengenai aktivitas guru dalam proses pembelajaran dipeoleh dengan melakukan pengamatan menggunakan lembar observasi aktivitas guru, (3) data mengenai hasil belajar siswa, diperoleh dengan melakukan tes hasil belajar di setiap akhir Siklus I dan Siklus II. (4) data mengenai respon siswa diperoleh dengan menggunakan angket respon siswa. 


\section{HASIL DAN PEMBAHASAN}

\subsection{Hasil Tahap Perencanaan Siklus I}

Pada tahap perencanaan siklus I ini peneliti telah menelaah silabus kurikulum tahun 2010 dengan materi pembelajaran matematika kelas VII semester genap pada satuan pendidikan SMP tentang Segiempat yang dilaksanakan selama empat kali pertemuan. Selanjutnya membuat RPP model pembelajaran Kooperatif Tipe CIRC yang menjadi pedoman peneliti dalam melaksanakan pembelajaran di kelas dan LKS sebagai latihan menyelesaikan soal-soal. Bagian akhir siklus I, menganalisis dan menyeleksi soalsoal yang akan diberikan kepada siswa setelah menerapkan model pembelajaran Kooperatif Tipe CIRC yang menghasilkan Kisi-kisi Tes Hasil Belajar Siklus I dengan tujuan mengukur peningkatan hasil belajar siswa melalui model pembelajaran Kooperatif Tipe CIRC selama siklus I.

\subsection{Tahap Pelaksanaan Tindakan Siklus I}

Hasil observasi terhadap pengelolaan kelas dan aktivitas guru melaksanakan pembelajaran diperoleh pelaksanaan pembelajaran setiap pertemuan yaitu Pertemuan Pertama siswa masih banyak yang bermain dan hanya 1-2 orang siswa yang aktif menjawab pertanyaan yang diajukan guru. Guru menyampaikan model pembelajaran yang digunakan yaitu model pembelajaran kooperatif tipe CIRC. Pada saat guru membagi siswa ke dalam kelompok secara acak dengan karakteristik yang heterogen untuk menyelesaikan LKS yang dibagikan kepada masing-masing kelompok Siswa diarahkan dalam bekerja kelompok mengikuti langkah-langkah model pembelajaran kooperatif tipe CIRC. Pertemuan Kedua Guru lebih memaksimalkan pengelolahan pembelajaran melalui model pembelajaran kooperatif tipe CIRC untuk mengatasi masalah yang ada pada pertemuan pertama. Kegiatan proses belajar mengajar sudah mulai berjalan lancar dan siswa mulai aktif bertanya. Pada pelakasanaan model pembelajaran kooperatif tipe CIRC masih ada siswa yang belum mampu menafsirkan isi soal, menuliskan apa yang diketahui dan apa yang ditanyakan yang ada pada LKS, hal ini membuktikan bahwa siswa belum mampu bekerja sama dalam menyelesaikan permasalahan yang dihadapinya. Pertemuan Ketiga, kegiatan proses belajar mengajar sudah mulai berjalan lancar. Kelas sudah lebih tenang dari pertemuan pertama dan kedua. Beberapa kelompok sudah mampu menafsirkan isi soal dan menuliskan apa yang diketahui dan apa yang ditanyakan dari soal pada LKS yang diberikan serta menuliskan penyelesaian soal secara terurut, hal ini menunjukkan bahwa siswa yang dapat memahami materi yang telah dibahas sudah lebih banyak dibanding pertemuan kedua meskipun pada saat diskusi berlangsung masih ada beberapa yang belum dapat mempertanggungjawabkan bagian materinya kepada kelompok yang lain di depan kelas, hal ini membuktikan bahwa setelah tiga kali pertemuan ternyata siswa masih belum terbiasa belajar secara kooperatif. Secara umum hasil tindakan ini menunjukkan kemampuan siswa dalam memahami konsep segiempat masih sangat kurang. Oleh karena itu peneliti merasa masih perlu melakukan tindakan selanjutnya untuk mengatasi masalah-masalah tersebut. Setelah 3 kali pertemuan, siswa diberikan tes hasil belajar dalam Siklus I yang berbentuk uraian dan selanjutnya diadakan refleksi terhadap tindakan yang dilakukan.

\subsection{Hasil Observasi dan Evaluasi Siklus I}

Pada Siklus I ini, terlihat siswa masih banyak yang bermain-main saat guru menyampaikan tujuan pembelajaran dan memberi motivasi kepada siswa pada pertemuan pertama setelah pertemuan kedua, ketiga dan keempat suasana kelas sudah mulai kondusif. Pada saat guru membagi siswa menjadi 7 kelompok dengan karakteristik yang 
heterogen, siswa sangat sulit diarahkan, banyak siswa yang tidak mengetahui teman kelompoknya dan posisi tempat duduk yang sulit diatur sehingga kelas menjadi ribut.

Setelah siswa berkumpul dikelompoknya, guru membagikan LKS kepada masing-masing kelompok kemudian menugaskan tiap anggota kelompok untuk menyelesaikan soal yang ada pada LKS, kemudian salah satu anggota kelompok membaca atau beberapa anggota membaca soal tersebut. Semua anggota kelompok membuat ikhtisar atau rencana penyelesaian soal.

Pada siklus I ini belum terlihat sikap kerjasama siswa, siswa masih lebih senang bekerja sendiri-sendiri, adapula siswa yang acuh tak acuh terhadap tugas yang diberikan kepadanya. Hal ini mengakibatkan para anggota kelompok sebagian besar tidak dapat mempertanggungjawabkan bagian materinya. Ini dibuktikan dengan evaluasi pada akhir pertemuan tentang tugas kelompoknya sehingga ada kelompok yang cuma perwakilannya saja yang menjawab evaluasi dari gurunya.

Evaluasi terhadap pelaksanaan tindakan juga didasarkan pada Tes Hasil Belajar dalam bentuk uraian. Setelah peneliti memeriksa tes Evaluasi Siklus I terlihat masih banyak siswa yang belum mengerti tahap-tahap penyelesaian soal yang ada. pada Siklus I

Berikut ini disajikan data-data Tes Hasil Belajar matematika siswa kelas VIIa

Tabel 1 Statistik Skor Hasil Belajar Matematika Siswa Kelas VII4 SMP Negeri 26 Makassar Siklus I

\begin{tabular}{|l|l|}
\hline \multicolumn{1}{|c|}{ Statistik } & Nilai Statistik \\
\hline Subjek penelitian & 32 \\
Skor maksimum & 85 \\
Skor Minimum & 30 \\
Rentang skor & 55 \\
Rata-rata & 54,47 \\
Standar deviasi & 16,24 \\
Variansi & 263,74 \\
\hline
\end{tabular}

Jika skor siswa dikelompokkan ke dalam pengkategorian hasil belajar, maka akan tampak pada Tabel berikut ini:

Tabel 2 Frekuensi dan Persentase Skor Hasil Belajar Siswa SMP Negeri 26 Makassar pada Siklus I

\begin{tabular}{|c|c|c|c|c|}
\hline No & Skor & Kategori & Frekuensi & Persentase \\
\hline 1 & $0-34$ & $\begin{array}{l}\text { Sangat } \\
\text { rendah }\end{array}$ & 2 & 6.2 \\
\hline 2 & $35-64$ & Rendah & 20 & 58.2 \\
\hline 3 & $65-79$ & Sedang & 9 & 15.6 \\
\hline 4 & $80-89$ & Tinggi & 1 & 3.1 \\
\hline 5 & $90-100$ & $\begin{array}{l}\text { Sangat } \\
\text { tinggi }\end{array}$ & - & - \\
\hline \multicolumn{3}{|c|}{ Jumlah } & 32 & 100 \\
\hline
\end{tabular}

Dari Tabel 1 dan Tabel 2 maka dapat dikemukakan bahwa skor rata-rata hasil belajar matematika siswa kelas VII4 SMP Negeri 26 Makassar setelah dilakukan tindakan pembelajaran kooperatif tipe CIRC pada siklus I sebesar 54,47 dari skor ideal 100 berada dalam kategori "sedang" yang dicapai oleh siswa dengan standar deviasi 16,24. Data ini menunjukkan bahwa tingkat penguasaan materi segiempat yang dipelajari pada siklus I sebesar 54,47. 


\subsection{Refleksi}

Di awal penelitian, guru membentuk kelompok yang beranggotakan 4 sampai 5 orang siswa. Kelompok tersebut merupakan kelompok heterogen yang mewakili hasilhasil akademis, dan jenis kelamin. Kemudian guru menyampaikan tujuan dan memberikan motivasi serta menyampaikan akan diterapkan model pembelajaran kooperatif tipe CIRC. Setelah pelaksanaan pembelajaran selama tiga kali pertemuan terihat bahwa keaktivan siswa dalam proses belajar-mengajar sudah mulai meningkat. Namun, masih banyak juga siswa yang bersikap pasif dan belum berani untuk berbicara didepan kelas. Berdasarkan Tes Hasil Belajar Siklus I, terdapat 17 siswa dari 33 orang siswa yang mencapai ketuntasan individualnya atau sebesar 53,12 \%. Dengan demikian diperlukan adanya tindakan perbaikan pembelajaran lebih lanjut.

\subsection{Rekomendasi}

Setelah merefleksi hasil pelaksanaan siklus I, diperoleh suatu gambaran tindakan yang akan dilaksanakan pada siklus II, sebagai perbaikan dari tindakan yang telah dilakukan pada siklus I sehinga tindakan yang akan dilakukan pada siklus II antara lain: (1) guru menjelaskan materi pokok secara lebih rinci dan lebih memotivasi siswa dengan menceritakan secara ringkas tokoh bersejarah khususnya dalam ilmu Matematika, (2) lebih memperketat pengawasan setiap kelompok dengan membimbing langsung siswa yang masih kesulitan memahami materi yang dibahas dan memberi sanksi kepada siswa yang tidak aktif dalam diskusi, (3) menyebut nama siswa secara acak untuk mempersentasikan hasil diskusi kelompoknya, (4) menjanjikan nilai tambah kepada siswa yang aktif.

\subsection{Deskripsi Hasil Penelitian Siklus II \\ 3.6.1 Perencanaan}

Siklus II dilaksanakan sebanyak 3 kali pertemuan. Pada pertemuan kelima, keenam, ketuju yang diajarkan adalah pengertian, sifat-sifat, keliling, dan luas belah ketupat, layang-layang serta trapezium secara berurutan. Sebagaimana yang telah dipaparkan pada BAB III bahwa perencanaan dan pelaksanaan tindakan pada Siklus II ini pada dasarnya mengulang langkah-langkah pada Siklus I. Namun yang berbeda adalah pada Siklus II dilakukan penyempurnaan dan perbaikan terhadap kendala yang muncul pada Siklus I. Perencanaan yang dilaksanakan meliputi pembuatan RPP, pembuatan lembar kerja siswa dan analisis dan seleksi soal tes siklus untuk mengukur peningkatan hasil belajar.

\subsubsection{Pelaksanaan tindakan}

Adapun gambaran umum tindakan pada pelaksanaan pembelajaran di Siklus II ini sebagai berikut:

\section{Pertemuan kelima.}

Pada pertemuan ini terlihat siswa sudah lebih bersemangat untuk memulai pelajaran, demikian halnya ketika guru mengajukan beberapa pertanyaan tentang materi sebelumnya, siswa terlihat lebih siap menjawab pertanyaan-pertanyaan yang diajukan.

Selanjutnya guru meminta siswa untuk berkumpul kembali dengan kelompok yang sudah ditentukan, kemudian guru membagikan LKS kepada masing-masing kelompok kemudian menyebutkan nama-nama siswa yang bertanggungjawab menjelaskan kepada kelompok yang lain. Selama diskusi berlangsung, siswa yang mampu memahami materi yang dibagikan sudah meningkat. Dari hasil persentasi dapat disimpulkan bahwa siswa telah mampu menyelesaikan soal yang telah diberikan sehingga 
mereka dapat menemukan sendiri solusi dari permasalahan yang dihadapinya. Selanjutnya guru menutup pelajaran dan mengumpulkan jawaban LKS yang telah dikerjakan oleh masing-masing kelompok.

\section{Pertemuan keenam.}

Pada pertemuan ini dilaksanakan dengan menggunakan RPP kelima, peneliti memfokuskan perhatian terhadap kendala yang dihadapi siswa dalam menyelesaikan masalah yang ada. Setelah peneliti memerintahkan siswa untuk menyelesaikan LKS yang dibagikan kepada masing-masing kelompok, kemudian peneliti mengadakan bimbingan secara langsung kepada siswa yang masih kesulitan memahami materi, dengan demikian masing-masing anggota kelompok telah dapat mempertanggungjawabkan bagian materi yang diberikan, sikap kerjasama siswa sudah mulai terlihat.

\section{Pertemuan ketujuh}

Setelah pelaksanaan pembelajaran pada pertemuan ketujuh, kemudian diadakan Tes Hasil Belajar Siklus II dalam bentuk uraian.

Pada Siklus II terlihat bahwa proses belajar mengajar telah menemukan metode yang tepat sesuai dengan yang diharapkan. Setiap siswa mulai terbiasa dengan kegiatan yang dilakukan. Selain itu, meningkatnya frekuensi siswa yang mengajukan diri maju di depan kelas mengerjakan soal untuk mewakili kelompoknya. Ini menunjukkan bahwa rasa percaya diri dan keberanian berbicara siswa dalam proses belajar mengajar sudah tertanam.

\subsubsection{Observasi dan evaluasi}

Pada Siklus II terlihat bahwa proses belajar mengajar telah menemukan metode yang tepat sesuai dengan yang diharapkan. Setiap siswa mulai terbiasa dengan kegiatan yang dilakukan. Selain itu, meningkatnya frekuensi siswa yang mengajukan diri mempersentasikan hasil diskusi kelompoknya. Ini menunjukkan bahwa rasa percaya diri dan keberanian berbicara siswa dalam proses belajar mengajar sudah tertanam.

Jadi, secara umum dapat dikatakan bahwa seluruh kegiatan pada siklus II ini mengalami peningkatan dibanding dari siklus I. Hal ini dapat terlihat dari keseriusan siswa memperhatikan pelajaran yang diberikan, keaktifan siswa untuk bertanya dan memberi tanggapan tentang materi yang dibahas, dan keaktifan siswa mengajukan diri untuk mewakili kelompoknya persentasi semakin meningkat. Demikian pula halnya setelah diberi tes, dapat dikatakan bahwa hasil yang diperoleh siswa mengalami peningkatan jika dibandingkan dengan tes yang dilaksanakan di akhir siklus I. Sebagaimana ditunjukkan pada table 3 dibawah ini.

Tabel 3 Statistik Skor Hasil Belajar Matematika Siswa Kelas VII4 SMP Negeri 26

\begin{tabular}{|l|c|}
\multicolumn{2}{c}{ Makassar Siklus II } \\
\hline \multicolumn{1}{|c|}{ Statistik } & Nilai Statistik \\
\hline Subjek penelitian & 32 \\
Skor maksimum & 94 \\
Skor minimun & 52 \\
Rentang skor & 42 \\
Rata-rata & 69,34 \\
Standar deviasi & 11,01 \\
Variansi & 121,33 \\
\hline
\end{tabular}


Jika skor siswa dikelompokkan ke dalam pengkategorian hasil belajar, maka akan tampak pada Tabel 4 berikut ini:

Tabel 4 Frekuensi dan Persentase Skor Hasil Belajar Siswa 26 Makassar Kelas VII4 SMP Negeri Siklus II

\begin{tabular}{|c|c|c|c|c|}
\hline No & Skor & Kategori & Frekuensi & Persentase \\
\hline 1 & $0-34$ & $\begin{array}{c}\text { Sangat } \\
\text { rendah }\end{array}$ & - & - \\
\hline 2 & $35-64$ & Rendah & 13 & \\
\hline 3 & $65-79$ & Sedang & 3 & .2 \\
\hline 4 & $80-89$ & Tinggi & 9.3 \\
\hline 5 & $90-100$ & $\begin{array}{c}\text { Sangat } \\
\text { tinggi }\end{array}$ & 2 & 6.2 \\
\hline \multicolumn{5}{|c|}{ Jumlah } \\
\hline
\end{tabular}

Dari Tabel 3 dan Tabel 4 maka dapat disimpulkan bahwa hasil belajar matematika siswa kelas VII4 SMP Negeri 26 Makassar setelah dilakukan tindakan pembelajaran kooperatif tipe CIRC pada siklus II berada dalam kategori "tinggi" dengan skor rata-rata 69,34 dari skor ideal 100 yang mungkin dicapai oleh siswa dengan standar deviasi 11,01. Data ini menunjukkan bahwa tingkat penguasaan materi segiempat yang dipelajari pada siklus II sebesar 69,34. Sedangkan median berpusat pada skor 69,34, artinya 50\% skor siswa berada di bawah atau sama dengan 69,34 dan $50 \%$ skor siswa berada di atas atau sama dengan 69,34.

\subsubsection{Refleksi}

Berdasarkan rangkaian kegiatan pada Siklus II, mulai dari perencanaan, pelaksanaan tindakan, observasi dan evaluasi semua mengalami kemajuan kearah positif yang signifikan. Semua siswa aktif dalam melaksanakan tugas-tugas belajar, tujuan pembelajaran telah dicapai dengan maksimal, ketuntasan belajar klasikal yang ditetapkan sekolah telah tercapai tanpa remedial yang ditetapkan sekolah.

\subsubsection{Respon Siswa}

Siswa memberikan komentar bahwa matematika adalah pelajaran yang sulit, meskipun ada juga beberapa siswa yang menganggap bahwa belajar matematika itu menyenangkan. Namun setelah diterapkan model pembelajaran kooperatif tipe $C I R C$ sebagian besar siswa merasa senang belajar matematika karena menurut mereka metode ini menuntut adanya kerja sama yang baik antara sesama anggota kelompok dalam menemukan konsep matematika dan menyelesaikan permasalahan yang diberikan dengan menghubungkan materi yang dipelajari dalam kehidupan sehari-hari serta dapat saling bertukar pikiran untuk mencari jawaban yang benar sehingga berkesan dan mudah diingat. Disamping itu siswa yang pemahamannya kurang, dapat termotivasi dan berusaha untuk menyelesaikan permasalahan yang diberikan dengan bantuan anggota kelompoknya yang lebih pintar, dengan demikian siswa semakin percaya diri untuk berani tampil persentasi didepan kelas.

\subsection{Pembahasan}

Pembelajaran kooperatif tipe $C I R C$ dalam penelitian ini, kelas dibagi menjadi 7 kelompok yang anggotanya terdiri atas 4 atau 5 orang siswa dengan karakteristik yang heterogen. Bahan akademik disajikan kepada siswa dalam bentuk LKS, dimana tiap kelompok mempunyai masalah/materi yang sama dan tiap siswa bertanggung jawab 
untuk mempelajari satu bagian dari bahan akademik tersebut dan mampu menafsirkan isi soal, menuliskan yang diketahui dan yang ditanyakan serta menuliskan penyelesaian soal secara terurut. Para anggota dari tim yang berbeda memiliki tanggung jawab untuk mempelajari suatu bagian akademik yang sama. Setelah diadakan diskusi dalam kelompok para siswa dievaluasi secara individual atau kelompok mengenai bahan yang telah dipelajari melalui persentasi dan jawaban LKS yang dikumpulkan setiap akhir pertemuan.

Dalam penelitian ini, data yang di peroleh berupa data kuantitatif dan data kualitatif. Data kualitatatif berupa lembar observasi siswa dan guru, Lembar observasi tersebut berisi indikator-indikator yang akan diamati dalam proses belajar-mengajar. Sedangkan data kuantitatif berupa tes hasil belajar yang dilaksanakan setiap akhir siklus. Data tersebut disajikan dalam bentuk tabel yang terdapat pada Lampiran C.

Berdasarkan hasil pengamatan yang diperoleh di kelas VII4 SMP Negeri 26 Makassar menunjukkan ketercapaian indikator yang diamati dalam kegiatan belajarmengajar dalam beberapa aspek dengan melihat frekuensi siswa yang aktif dalam setiap aspek yang diamati.

Pada siklus I, terlihat masih banyak siswa yang belum antusias dan belum menunjukkan keseriusannya dalam kegiatan belajar-mengajar, hal ini disebabkan karena siswa belum terlatih dalam kegiatan kerja kelompok. Situasi ini mengakibatkan masih adanya siswa yang belum mendapatkan hasil yang maksimal pada tes hasil belajarnya dan tujuan yang diharapkan belum tercapai.

Pada siklus II, terlihat bahwa keseriusan dan semangat siswa untuk bekerja secara kooperatif sudah mengalami peningkatan dilihat dari lembar observasi siswa dari tiap pertemuan. Keberhasilan pada siklus kedua ini merupakan hasil refleksi dari siklus pertama dengan berbagai usaha untuk memperbaiki pembelajaran pada siklus kedua.

Setelah pelaksanaan tindakan siklus I, diperoleh informasi bahwa hasil belajar matematika siswa berada pada kategori sedang berdasarkan pada pengkategorian skala lima, dengan skor rata-rata hasil belajar matematika siswa sebesar 54,47 yakni hanya ada 14 orang dari 32 orang siswa yang mencapai ketuntasan individualnya atau sebesar 43,6 $\%$. Jadi pada pelaksanaan siklus I ini, penerapan model pembelajaran kooperatif tipe CIRC dikelas VII4 SMP Negeri 26 Makassar belum dikatakan tuntas belajarnya.

Hasil belajar matematika siswa mengalami peningkatan, keberhasilan ini dipacu oleh refleksi pada siklus I. Dari hasil analisis data yang diperoleh pada siklus II, hasil belajar siswa berada pada kategori tinggi berdasarkan pada pengkategorian skala lima, dengan skor rata-rata hasil belajar matematika siswa sebesar 69,34 yakni 28 orang dari 32 orang siswa yang mencapai ketuntasan individualnya atau sebesar $87,5 \%$. Jadi pada pelaksanaan siklus II ini ketuntasan belajar klasikal telah tercapai melalui penerapan model pembelajaran kooperatif tipe 3 dikelas VII4 SMP Negeri 26 Makassar.

\section{KESIMPULAN}

Penelitian yang dilakukan adalah penelitian tindakan kelas yang dilakukan dua siklus dengan keaktifan siswa dalam proses belajar mengajar mengalami peningkatan dalam hal : (1) perhatian siswa dalam pembahasan materi pelajaran, (2) keaktifan siswa dalam diskusi kelompok, (3) kesungguhan siswa dalam menyelesaikan soal yang diberikan dan hasil belajar matematika yang dicapai siswa kelas VII4 SMP negeri 26 Makassar mengalami peningkatan.

Penerapan model pembelajaran kooperatif tipe CIRC dalam proses belajar mengajar dapat meningkatkan hasil belajar matematika siswaa kelas VII4 SMP Negeri 26 Makassar 


\section{DAFTAR PUSTAKA}

Abdurrahman, 1999. Pendidikan Bagi Anak Berkesulitan Belajar. Jakarta: PT. Rineka Cipta.

Departemen Pendidikan Nasional. 1993. Evaluasi dan Penilaian. Jakarta: Proyek Peningkatan Mutu Guru. Dirjen DIKDASMEN.

Dimyati \& Mudjiono, 2009. Belajar dan Pembelajaran. Jakarta: PT. Rineka Cipta.

Gagne, R.M. 1988. Prinsip-prinsip Belajar untuk Pengajaran (Essential of Learning for Instruction). Surabaya: Usaha Nasional.

Hudoyo, H. 2003. Pengembangan Kurikulum dan Pembelajaran Matematika. Edisi Revisi. Malang: Universitas Negeri Malang.

Hudoyo, H. 1990. Strategi Mengajar Belajar Matematika. Malang: IKIP Malang.

Inayah, N. 2007. Keefektifan Penerapan Model Pembelajaran Kooperatif Tipe CIRC (Cooperative Integrated Reading And Composition) Terhadap Kemampuan Pemecahan Masalah Pada Pokok Bahasan Segiempat. (Online). http://techonly13.wordpress.com/, diakses tanggal 22 November 2010.

Jihad, A. \& Haris, 2010. Evaluasi Pembelajaran. Yogyakarta: Multi Press.

Kunandar, 2009. Langkah Mudah Penelitian Tindakan Kelas Sebagai Pengembangan Profesi Guru. Jakarta: Rajawali Pers.

Mansyur, Rasyid, H. \& Suratno. 2009. Asesmen Pembelajaran di Sekolah. Yogyakarta: Multi Pressindo.

Mansyur, Rasyid, H. \& Suratno. 2009. Penelitian Tindakan Kelas untuk Guru dan Calon Guru. Yogyakarta: Multi Pressindo.

Mazjun, 2009. Model Pembelajaran Kooperatif (Online). http://mazjun.blog.uns.ac.id/2009/10/16/model-pembelajaran-kooperatif/. Diakses Tanggal 22 November 2010.

Nurdin, 2009. Pendidikan dan Latihan Profesi Guru (Modul Matematika SMA). UNM Makassar.

Nurhadi. 2003, Pembelajaran Kontekstual dan Penerapannya dalam KBK, Malang: Penerbit Universitas Negeri Malang.

Sahabuddin. 2007, Mengajar dan Belajar Dua Aspek dari Suatu Proses disebut Pendidikan, Makassar: Badan Penerbit UNM.

Sardiman. 2000. Interaksi dan Motivasi Belajar Mengajar. Jakarta: Raja Grafindo Persada.

Slavin, R.E. 2008. Cooperative Learning (Teori, Riset, dan Praktik), Cetakan Ke-3, diterjemahkan Oleh Nurulita. Jakarta: Nusa Media.

Sudjana, 2006, Penilaian Hasil Proses Belajar Mengajar, Bandung: PT. Remaja Rosdakarya.

Suherman, dkk, 2003, Strategi Pembelajaran Matematika Kontemporer. Bandung: Universitas Pendidikan Indonesia.

Rahaju, E.B. Sulaiman, R. Eko S.T.Y. Budiarto, M.T \& Kusrini, 2008. Matematika SMP Kelas VIII. Pusat Perbukuan Deepartemen Pendidikan Nasional.

Rosyadi, M. A. 2010. Model Pembelajaran Kooperatif Tipe CIRC (Online). http://matematikacerdas.wordpress.com/2010/01/28/model-pembelajaran-kooperatiftipe-circ, Diakses tanggal 27 Desember 2010.

Riyanto, 2010. Paradigma Baru Pembelajaran. Jakarta: Kencana Perdana Media Group.

Winkel, 2004. Psikologi Pendidikan. Yogyakarta: Media Abadi 